\title{
Relation of Immune Response to Development of Central Nervous System Lesions in Virus Infections of Man
}

\author{
H. E. WEBB,* D.M., M.R.C.P. ; C. E. GORDON SMITH,† M.D., M.R.C.P.
}

Brit. med. F., 1966, 2, 1179-1181

There seems to be a case for presenting a more fully developed version of the ideas put forward in a letter to the British Medical fournal (Webb and Smith, 1964) concerning the possible causation of central nervous system (C.N.S.) lesions in virus infections. This somewhat speculative article has therefore been written in the hope of stimulating thought, discussion, and further research by clinicians, virologists, and immunologists.

When large numbers of sera from human populations are tested, antibody to viruses, such as poliomyelitis or Japanese encephalitis, which typically cause C.N.S. disease, is of ten found in people with no history of C.N.S. illness. Inapparent infection rates with such viruses vary from $99.9 \%$ for poliomyelitis and Japanese encephalitis to about $90 \%$ for eastern and western encephalitis. Perhaps the major feature of meningoencephalitis in man which therefore requires explanation is why only a very small proportion of such infections actually cause a clinically recognizable C.N.S. disturbance.

When there is a C.N.S. involvement the illness is fundamentally biphasic: a mild, often missed, febrile illness is followed by a quiescent period which may vary from 1 to 14 days, and then by the C.N.S. disturbance. The initial phase may even be afebrile. The picture in man is perhaps best seen in European biphasic meningoencephalitis, but Kyasanur Forest disease virus in experimental animals (Webb and Chatterjea, 1962) and humans (Webb and Lakshmana Rao, 1961) and Langat virus in humans (Webb et al., 1966) also cause biphasic illnesses. There is a similar course of events in many other virus infections, including poliomyelitis (Horstmann et al., 1954).

\section{Viraemic Period}

After infection with tick-transmitted viruses, primary multiplication probably occurs in the regional lymph node (Malkova, 1960a ; Malkova et al., 1961) and is followed by viraemia, during which further multiplication probably takes place in the white blood cells (Webb and Chatterjea, 1962; Webb and Burston, 1966 ; Webb et al., 1966), and susceptible cells throughout the body become infected. This viraemic period makes up the first phase of the illness, and during it the virus has sensitized the immunological mechanisms, and viraemia ends as antibody develops. In naturally occurring cases, and in experimentally infected animals, virus can rarely be detected in the blood after the onset of C.N.S. symptoms, but antibody is by then usually demonstrable in the blood. During the period of viraemia the titre of the virus in any organ rarely exceeds that of the blood until the viraemia is terminating. Virus multiplication then proceeds and may reach high titres and persist for varying periods in those organs with susceptible cells. Cellular destruction undoubtedly results from this, but its degree is uncertain and viruses can multiply in cells without killing them.

In mice, Malkova (1960b) found substantial amounts of virus in every organ tested at a time when there was a sub-

\footnotetext{
- Consultant Neurologist and Senior Lecturer, St. Thomas's Hospital and Medical School, London.

+Director, Microbiological Research Establishment, Porton, Salisbury,

Wilts.
}

stantial amount of antibody but no virus in circulation. In a monkey dying 27 days after inoculation with Kyasanur Forest disease virus, virus was recovered from both brain and skeletal muscle in the presence of a high blood antibody level (Webb, 1961). In the treatment of human neoplastic disease with Langat and Kyasanur Forest disease viruses (Webb et al., 1966) virus was recovered at necropsy from three patients in whom viraemia had ceased and antibody was readily detectable-from the C.N.S. in two, and from secondary tumour, spleen, and adrenal gland. Thus there is plenty of evidence that virus persists in tissues, including those of the C.N.S., after antibody has appeared in the circulation.

\section{Neuronal Damage}

In encephalomyelitis of man, monkeys, and other large species histological examination of the C.N.S. shows a mixture of inflammatory and degenerative changes, either of which may predominate in a particular case. Dr. I. Zlotnik (personal communication), from a pathological examination of the C.N.S. of a large number of cases of fatal louping-ill in sheep, has observed that in young and highly susceptible animals the picture is predominantly one of neuronal destruction, while in older and less susceptible animals (particularly in those partially immune) the condition is predominantly inflammatory and neuronal changes are minimal. When small experimental animals such as mice are inoculated into the brain, death occurs earlier than in peripherally inoculated animals-in under two days with some viruses. In such circumstances antibody has either not appeared or is at a very low level by the time of death, and the histological picture is primarily of neuronal destruction. Although antibody may start developing very early in virus infections, Uhr et al. (1962) showed that very small doses of bacteriophage inoculated into guinea-pigs produced antibodies within 24 hours. At present our tests for detecting early development of antibody are not sensitive enough.

Many experiments indicate that antigen-antibody or hypersensitivity reactions may be of some importance in the pathogenesis of these diseases. Mice inoculated intraperitoneally with Venezuelan equine encephalitis virus develop encephalomyelitis. However, Berge et al. (1961) have shown that if they are also inoculated with Venezuelan equine encephalitis immune serum at a specific time after infection the histological changes in the C.N.S. are more pronounced than in those inoculated with virus only. Gleiser et al. (1961) showed that the administration of cortisone to monkeys inoculated with Venezuelan equine encephalitis virus, just before onset of the second phase of the disease and at the time of appearance of antibodies, caused a marked suppression of the inflammatory response in the C.N.S. It did not exacerbate the clinical disease, nor did it modify the antibody response.

We have been able to confirm these findings in mice infected with Langat and Semliki Forest viruses. In mice inoculated with Langat virus, either immune serum or cortisone affects the outcome of the infection only if given at very specific times. The maximal detrimental effect of immune serum occurs if it is given at, or just after, the maximum of the viraemia. Corti- 
sone is beneficial only if given 24 to 48 hours preceding paralysis, which starts one or two days after viraemia ceases. In mice infected intraperitoneally with Semliki Forest virus and given antibody 24 hours later, fatty changes in the liver, inflammatory changes in the brain, and death all occurred earlier than in the controls. In the immune serum group the subsequent virus titres in the liver and kidney were lower, but those in the brains were not affected.

\section{Lymphocytic Choriomeningitis Experiments}

Rowe (1956) and Hotchin and Weigand (1961) demonstrated that if mice were $x$-irradiated before infection with lymphocytic choriomeningitis virus there was a slight increase of virus titre in brain and blood, but the clinical illness was less severe and the mortality decreased. Collins et al. (1961) showed that histological evidence of meningoencephalitis or hepatitis in such animals was very much reduced. Goldberg et al. (1935) also showed that $x$-irradiated mice inoculated intracerebrally with St. Louis encephalitis virus had an increased survival time. Levy and Haas (1958) showed that mice infected with lymphocytic choriomeningitis virus were markedly protected by treatment with a folic acid antagonist methotrexate (Amethopterin) in spite of its prolongation of viraemia. Similar results were obtained in mice kept on a folic-acid-deficient diet (Haas et al., 1957). All these procedures have a depressing effect on the immunological mechanisms and probably exert their protective effect in this way.

It is not unreasonable to suppose that viruses may persist for months or years inside cells. Because of the lack of an immune response in these lymphocytic choriomeningitis experiments the virus persisted longer than in infected normal animals. Virus is neutralized by antibody only outside cells, but may survive a long time in cells, provided that it does not destroy its host cell, or has the ability to pass to contiguous cells without coming in contact with neutralizing antibody, as appears to be the case in herpes simplex infections, which remain latent for long periods. Individual cells in the C.N.S. probably have a longer life-span than most other cells in the body. Also there is probably less extracellular fluid, relative to cells, in the C.N.S. as compared with other organs. If the cerebrospinal fluid reliably represents the extracellular fluid of the C.N.S., then antibody reaches the C.N.S. much more slowly than other tissues (Lipton et al., 1965; Webb et al., 1966). These factors may help to prolong the life of virus in cells of the C.N.S. Such persistent infections are difficult to demonstrate, because, as a rule, tissues are ground up to release virus in the presence of antibody-containing fluids, so that low amounts of virus are unlikely to be detected. Technique for culturing the cells of the C.N.S. must be further developed, so that antibody can be diluted out and virus recovered.

\section{Antigen-Antibody Complexes}

There is little doubt that virus, if it has reached the C.N.S., is present there when antibody has appeared in the blood stream, and that encephalitis occurs at this time. The cells of preference for virus multiplication, and thus the sites of highest concentration of virus in the C.N.S., will vary in the different diseases, and could account for the difference in the histological appearances in poliomyelitis, arbovirus, and measles infections, to give examples. The predominantly perivascular distribution of the inflammatory changes in the C.N.S. suggests that this may be the site where suitable concentrations of antigen meet suitable concentrations of antibody. Antigen-antibody reactions are known to initiate inflammatory destructive tissue reactions, and blood complement levels fall because complement is fixed. The course of events in a viraemic virus infection closely resembles that described by Dixon (1964) for serum sickness: while protein antigen (virus) is circulating, antibody begins to appear and antigen-antibody complexes form in antigen excess and are therefore small (soluble). As antibody increases the antigen-antibody complexes increase in size and complement depletion becomes evident in the blood. These large antigenantibody complexes become localized where they adhere in small vessels or at sites where filtration of serum proteins occurs. Wherever these complexes become fixed, inflammatory reactions arise. In the C.N.S., meningeal and perivascular sites would be predicted by this model.

Lipton et al. (1965) have shown that, while IgG antibody of ten reaches the C.S.F., IgM antibody probably rarely does so. As IgM antibody is first to appear, the rare case in which this leaks into the C.N.S., at a time when virus multiplication is active, might well be the rare case in which encephalitis develops. The possible relation between IgM antibody and virus inflammatory lesions in general is suggested by the close parallel between the rise and fall of IgM globulin in infective hepatitis coincident with the course of the illness (Lee, 1965). Further evidence that antibody (probably $\operatorname{IgM}$ antibody) has some synergistic effect on virus infections of cells comes from Hawkes (1964), who found that with several arboviruses plaque counts were increased up to twelvefold by fowl antisera. Dr. J. S. Porterfield (personal communication), also working with arboviruses, has observed enlargement of plaques in the presence of certain amounts of antibody.

The question of whether antibody (particularly IgM antibody) is responsible, in combination with virus, for the inflammatory changes in virus infections certainly seems to merit investigation. Both Joklik (1964) and Kiellén (1965) have provided evidence that antibody-virus complexes adsorbed to cell surfaces cause profound changes in these surfaces. Anticellular antibody causes lysosomal activation in the cells it becomes adsorbed to and lysis in the presence of complement (Dumonde et al., 1965). Where virus antigen is attached to or forms part of the surface of a cell, antiviral antibody may act in a similar way. The protective effect of cortisone may be at least partially attributable to its known ability to stabilize lysosomes and prevent release of acid hydrolases (Thomas, 1964).

\section{Some Suggestions}

In the longer term, virus infections could be involved in the genesis of more chronic C.N.S. diseases. There are several forms which persistent virus infections of the C.N.S. may take : (a) in cells of great longevity virus infections may not be lethal but viruses may reproduce themselves slowly over long periods ; (b) virus materials may be incorporated into the cell genome, and this may lead to minor changes in the cell antigens; and (c) the lipoprotein-coated viruses, which acquire their outer coats at the surface of their host cells when they leave them, may cause chronically infected cells to have the same antigens on their surface as the virus.

Howatson et al. (1965) have demonstrated what appears to be a latent infection with a polyoma-like virus in the nuclei of glial cells in cases of progressive multifocal leucoencephalopathy. There appear to be two ways in which chronic demyelinating diseases such as disseminated sclerosis could result from virus infections of this sort: (1) exacerbations of such latent infections, due to stress factors such as trauma, intercurrent infection, etc., could lead to local virus antigenantibody reactions, an inflammatory reaction and tissue destruction leading to production of altered C.N.S. proteins which themselves would act as antigens; and (2) altered cells as in (b) and (c) above could themselves act as antigens. In either case these altered C.N.S. antigens would cause antibody formation, which, with chronic stimulation, would become more broadly reactive and in due course become reactive with normal C.N.S. tissue leading to a possible autoimmune type of disease. 


\section{Summary}

Clinical involvement of the central nervous system occurs only in a very small proportion of cases of virus infection, usually at the end of viraemia and often at a time when antibodies are already detectable. After the end of viraemia, virus multiplication appears to continue, at least for a period, in certain tissues, including the central nervous system. Encephalitis can present a histological picture, ranging from almost pure neuronal destruction to a largely inflammatory picture with minimal neuronal damage. The latter seems to be associated with the presence of partial immunity. There is experimental evidence that the administration of antibody at a critical time during the course of the infection may aggravate the inflammatory reaction, and that suppression of the immune response may ameliorate it. The possibility is discussed that the inflammatory aspect of the tissue reaction to virus infection is due to an interaction between the virus and the host immune response. Some ideas are put forward to suggest how virus infections might be responsible for some of the more chronic neurological disorders.

\section{REFERENCES}

Berge, T: O., Gleiser, C. A., Gochenour, W. S., jun., Miesse, M. L., and Tigertt, W. D. (1961). F. Immunol., 87, 509.

Collins, D. N., Weigand, H., and Hotchin, J. (1961). Ibid., 87, 682.

Dixon, F. J. (1964). In Injury, Inflammation, and Immunity, edited by L. Thomas, J. W. Uhr, and L. H. Grant, p. 257. Baltimore.
Dumonde, D. C., Bitensky, L., Cunningham, G. J., and Chayen, J. (1965). Immunology, 8, 25.

Gleiser, C. A., Gochenour, W. S., jun., Berge, T. O., and Tigertt, W. D. (1961). \%. Immunol., 87, 504.

Goldberg, S. A., Brodie, M., and Stanley, P. (1935). Proc. Soc. exp. Biol. (N.Y.), 32, 587.

Haas, V. H., Stewart, S. E., and Briggs, G. M. (1957). Virology, 3, 15.

Hawkes, R. A. (1964). Aust. F. exp. Biol. med. Sci., 42, 465.

Horstmann, D. M., McCollum, R. W., and Mascola, A. D. (1954). Y. exp. Med., 99, 355 .

Hotchin, J., and Weigand, H. (1961). f. Immunol., 87, 675.

Howatson, A. F., Nagai, M., and Zu Rhein, G. M. (1965). Canad. med. Ass. F., 93, 379 .

Joklik, W. K. (1964). Virology, 22, 620.

Kiellén, L. (1965). Immunology, 8, 585

Lee, F. I. (1965). Lancet, 2, 1043 .

Levy, H. B., and Haas, V. H. (1958). Virology, 5, 401.

Lipton, M. M., Steigman, A. J., and Dizon, F. C. (1965). F. infect. Dis., $115,356$.

Malkova, D. (1960a). Acta virol., 4, 233.

(1960b). Ibid., 4, 290.

二 Pala, F., and Sidak, Z. (1961). Ibid., 5, 101.

Rowe, W.' P.'(1956). Proc. Soc. exp. Biol. (N.Y.), 92, 194.

Rowe, W. P. (1956). Proc. Soc. exp. Biol. (N.Y.), 92, 194 . L. Thomas, J. W. Uhr, and L. H. Grant. Baltimore.

Uhr, J. W., Finkelstein, M. S., and Baumann, J. B. (1962). F. exp. Med., 115, 655 .

Webb, H. E. (1961). Kyasanur Forest Disease in Animals and Man, p. 22. D.M. Thesis. University of Oxford.

and Burston, J. (1966). Trans. roy. Soc. trop. Med. Hyg., 60, 325 .

and Chatterjea, J. B. (1962). Brit. 7. Haemat., 8, 401.

and Lakshmana Rao, R. (1961). Trans. roy. Soc. trop. Med. Hyg., 55, 284.

and Smith, C. E. G. (1964). Brit. med. F., 2, 569.

Wetherley-Mein, G., Smith, C. E. G., and McMahon, D. (1966). Ibid., 1, 258.

\section{Medical Memoranda}

\section{Amniotic Fluid Embolism : Case with Biochemical Findings}

Brit. med. 7., 1966, 2, 1181-1182

Elective caesarean section is generally a safe operation and amniotic fluid embolism is an extremely rare complication. Only one such case has previously been reported in the literature (Barno and Freeman, 1959). The mortality from amniotic fluid embolism is over 80\% (Aguillon et al., 1962; Scott, 1963 ; Geoghegan et al., 1964 ; Russell and Jones, 1965).

The following case presents the clinical features of amniotic fluid embolism and is, we believe, of particular interest because of the detailed evidence available.

\section{Case Report}

A women aged 37, whose two previous children had been delivered by elective caesarean section, was admitted in the 38th week of her third pregnancy on account of mild hypertension. Seven days after admission she was prepared for elective caesarean section.

Atropine $0.6 \mathrm{mg}$. was given subcutaneously one hour before operation. After preoxygenation for three minutes with a high flow of oxygen she was given thiopentone $250 \mathrm{mg}$. followed by suxamethonium $60 \mathrm{mg}$. The trachea was then intubated with a cuffed endotracheal tube without prior inflation of the lungs by face mask. On laryngoscopy there was no evidence of regurgitation of stomach contents and intubation was easy. Anaesthesia was maintained with $30 \%$ oxygen in nitrous oxide by means of a volume-cycled ventilator with a non-return circuit. Relaxation was maintained with D-tubocurarine.

The abdomen was opened through a Pfannenstiel incision and lower-uterine-segment caesarean section was performed. The child, a boy weighing $3.8 \mathrm{~kg}$., was in good condition at birth (Apgar score
9 at 2 minutes). Profuse bleeding occurred after delivery of the child and the uterus did not retract well. Manual removal of the placenta was performed and the uterus was closed in the usual manner. Ergometrine $0.5 \mathrm{mg}$. had been given intravenously with the birth of the child and uterine retraction was eventually satisfactory. The loss of blood during the operation was later estimated by a haemoglobin dilution technique at $1,850 \mathrm{ml}$. Compatible blood $1,000 \mathrm{ml}$. and plasma $500 \mathrm{ml}$. were infused during the operation.

During closure of the abdomen cyanosis and distension of the neck veins were noted and there was marked resistance to inflation of the lungs. At the conclusion of the operation atropine $1.2 \mathrm{mg}$. and neostigmine $2.5 \mathrm{mg}$. were given. Spontaneous ventilation was inadequate and cyanosis persisted despite the administration of $100 \%$ oxygen. At this stage amniotic fluid embolism was suspected and blood samples were taken for clotting tests (see Table I). The blood pressure was now $80 / 60 \mathrm{~mm}$. $\mathrm{Hg}$ and the pulse rate 140 . Obvious signs of massive pulmonary oedema were present ; this was confirmed by $x$-ray examination.

TABLE I.-Haematological Findings (Times are Hours After Conclusion of the Operation)

\begin{tabular}{|c|c|c|c|c|c|c|c|c|}
\hline Tin & $\begin{array}{l}\text { Fibrino- } \\
\text { gen } \\
\text { Titre }\end{array}$ & $\begin{array}{c}\text { Throm- } \\
\text { bin } \\
\text { Time }\end{array}$ & $\begin{array}{c}\text { Pro- } \\
\text { hrombir } \\
\text { Time }\end{array}$ & $\begin{array}{c}\text { Lysis } \\
\text { at } \\
37^{\circ} \mathrm{C} .\end{array}$ & $\begin{array}{l}\text { Foetal } \\
\text { Red } \\
\text { Cells }\end{array}$ & $\begin{array}{c}\mathrm{Hb} \\
\mathrm{g} .1 \\
100 \mathrm{~m} .\end{array}$ & \begin{tabular}{|l} 
W.B.C. \\
/cu. mm.
\end{tabular} & $\begin{array}{c}\text { Plate- } \\
\text { lets } \\
\text { / cu.mm }\end{array}$ \\
\hline 0 & $1: 128$ & $7 \mathrm{sec}$. & $14 \mathrm{sec}$. & Complete & None & & & \\
\hline$\frac{1}{6}$ & $\begin{array}{l}1: 128 \\
1: 128\end{array}$ & 7 ", & 14, & $\begin{array}{l}\text { 1n } 2 \mathrm{hr} \text {. } \\
\text { No } \mathrm{hs} \\
\text { No } 1 \mathrm{ys} \\
\text { after } \\
12 \mathrm{hr}\end{array}$ & & $13 \cdot 4$ & 32,700 & 183,000 \\
\hline
\end{tabular}

Manual intermittent positive-pressure ventilation (I.P.P.V.) with $100 \%$ oxygen was restarted, attempting to maintain a slight positive pressure during expiration. Examination of capillary blood revealed a moderate metabolic acidosis (see Table II). Sodium bicarbonate $100 \mathrm{mEq}$, aminophylline $250 \mathrm{mg}$., and hydrocortisone $200 \mathrm{mg}$. were given intravenously. At the same time an infusion of lowmolecular-weight dextran was started and $1,000 \mathrm{ml}$. was given. 